\title{
Situation of Forest Carbon Projects in Carbon Markets
}

\author{
Devlet TOKSOY ${ }^{1}$ Çiğdem ÖZTEKİN ${ }^{2}$ Mahmut M. BAYRAMOĞLU ${ }^{1 *}$ \\ ${ }^{1 *}$ Karadeniz Technical University, Faculty of Forestry, Department of Forest Engineering, Kanuni Campus, Trabzon, Turkey \\ ${ }^{2}$ Eastern Black Sea Forestry Research Institute, Trabzon, Turkey
}

How to cite: Toksoy, D., Öztekin, Ç. \& Bayramoğlu M.M. (2020). Situation of Forest Carbon Projects in Carbon Markets. J. Anatolian Env. and Anim. Sciences, 5(5), 872-881.

Atıf yapmak için: Toksoy, D., Öztekin, Ç. \& Bayramoğlu M.M. (2020). Karbon Piyasalarında Ormancılık Karbon Projelerinin Durumu. Anadolu Çev. ve Hay. Dergisi, 5(5), 872-881.

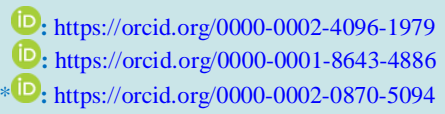

*Corresponding author's:

Mahmut M. BAYRAMOĞLU

Karadeniz Technical University, Department

of Forest Engineering, Kanuni Campus,

Trabzon, Turkey

$\varangle:$ mahmud@ktu.edu.tr

Mobile telephone: +90 (533) 5596093

Telephone : $+90(462) 3774143$

Fax $\quad:+90(462) 3257499$
Abstract: Global cooperation activities are being carried out within the framework of United Nations Framework Convention on Climate Change, Kyoto Protocol and Paris Agreements to stabilize the increasing greenhouse gas emissions in the atmosphere. Forests that play a key role in combating climate change are among the most important issues discussed during the climate change negotiations. There are two important pillars of the forestry sector in climate change. One is mitigation and the other is adaptation. Issues related to forestry interviewed in the scope of mitigation are Land use, land use change and forestry (LULUCF) and REDD +. The mechanism for mitigation is carbon markets. The rate of forestry projects in carbon markets is low. Turkey is traded on the voluntary carbon market is achieving very low income according to the mandatory carbon market. However, the carbon credits that are traded are provided by the renewable energy sector. These credits are in Turkey need to combat climate change in forestry activities both actively involved in the negotiations for the benefit of the mechanisms created in this context and should maintain this attitude. Turkey must make changes in the organizational and technical infrastructure besides negotiations.

Keywords: Climate change, kyoto protocol, carbon credit, forestry.

\section{Karbon Piyasalarında Ormancılık Karbon Projelerinin Durumu}

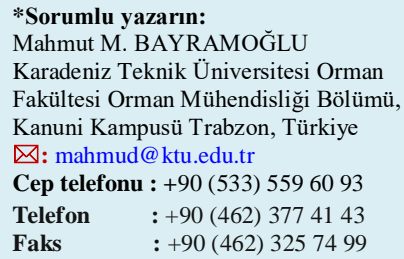

Öz: Atmosferdeki artan sera gazı emisyonlarını stabilize etmek için Birleşmiş Milletler İklim Değişikliği Çerçeve Sözleşmesi, Kyoto Protokolü ve Paris Anlaşmaları çerçevesinde küresel işbirliği çalışmaları yürütülmektedir. İklim Değişikliğiyle mücadele kilit rol oynayan ormanlar iklim değişikliği müzakerelerinde görüşülen en önemli konular arasında yer almaktadır. İklim değișikliğinde ormancılık sektörünün iki önemli ayağı bulunmaktadır. Bunlardan biri azaltım diğeri ise uyumdur. Azaltım kapsamında müzakerelerde görüşülen ormancılıkla ilgili hususlar Arazi kullanımı arazi kullanım değișikliği ve ormancılık (LULUCF) ve REDD konularıdır. Uyum ise; iklim değişikliğinin etkilerine yanıt olarak ekolojik, sosyal ve ekonomik sistemlerdeki düzenlemeleri ifade etmektedir ve iklim değişikliği nedeniyle ortaya çıkabilecek risklerin yönetimini kapsamaktadır. Ormancılıkta uyum iklim değişikliği odaklı sürdürülebilir orman yönetimi anlamına gelmektedir. Azaltımla ilgili mekanizma karbon piyasalarıdır. Karbon piyasalarında ormancıllk projelerinin oranı ise düşüktür. Türkiye gönüllü karbon piyasalarında işlem görmekte olup zorunlu karbon piyasalarına göre oldukça düşük gelir elde etmektedir. Bununla birlikte işlem gören karbon kredileri yenilenebilir enerji sektöründen sağlanmaktadır. $\mathrm{Bu}$ krediler içinde ormancılık faaliyetleri bulunmamaktadır. Bununla birlikte Türkiye, müzakereler haricinde de kurumsal ve teknik alt yapısında değişiklikler yapmak zorundadır. 


\section{INTRODUCTION}

Climate change is a complex problem that, although qualitatively environmental, has an impact on all areas of humanity's life. Global problems such as poverty, economic and sustainable development, population growth and the management of natural resources are affected. Therefore, it is a desired and expected situation that solutions for climate change come from research and development fields and all disciplines (Öztekin, 2019).

Climate change; In addition to natural climate change observed in comparable time periods, it is defined as a change in climate resulting from human activities that directly or indirectly disrupt the composition of the global atmosphere (UNFCCC, 1992). Global warming means that the global temperature has increased by $0.5 \mathrm{C}^{0}$ compared to a century ago and can be explained largely by the greenhouse effect. The greenhouse effect theory sees the increasing concentration of certain gases (carbon dioxide, chlorofluorocarbons, methane and nitrogen oxides) in the atmosphere as the cause of the problem. The most effective greenhouse gases are damp and carbon dioxide. $95 \%$ of the total greenhouse effect consists of these gases (Serengil, 1995).

The economic growth and population growth experienced with the industrial revolution caused the accumulation level of carbon dioxide and other greenhouse gases in the atmosphere to rise rapidly. Globally, economic growth and population growth continue to be the most important drivers of increases in carbon dioxide $\left(\mathrm{CO}_{2}\right)$ emissions from fossil fuel use (IPCC, 2014). According to the 5th Assessment Report of the Intergovernmental Panel on Climate Change (IPCC), the concentration of carbon dioxide, methane and nitrogen oxide in the atmosphere has increased unprecedentedly over the past 800,000 years. Emissions from fossil fuel use were shown as the primary cause of this increase, and net emissions from land use change were shown as the secondary cause (IPCC, 2013a).

Between 1750 and 2011, about half of the total human-induced $\mathrm{CO}_{2}$ emissions occurred in the last 40 years, and $2040 \pm 310 \mathrm{GtCO}_{2}$ total human-made $\mathrm{CO}_{2}$ emissions were added to the atmosphere. Since 1970, cumulative $\mathrm{CO}_{2}$ emissions from burning fossil fuels, cement production and ignition have tripled, and cumulative $\mathrm{CO}_{2}$ emissions from forestry and other land use have also increased by about $40 \%$. Annual $\mathrm{CO}_{2}$ emissions arising from fossil fuel combustion, cement production and exacerbation in 2011 were $34.8 \pm 2.9 \mathrm{GtCO}_{2}$, while the average annual emissions from forestry and other land use between 2002 and 2011 were $3.3 \pm 2.9 \mathrm{GtCO}_{2}$ (IPCC, 2014).

In Turkey forests are considered to be an important mechanism in the combat against climate change mitigation. However, there are no forestry carbon projects that can be subject to carbon markets until today. The reasons for this situation are high costs of credits obtained from forestry projects, methodology and calculation difficulties, lack of a measurable, reportable and verifiable system, etc. are the reasons.

In this study, the reasons for the low rate of forestry projects in carbon markets were investigated and the possibilities of increasing the share of forestry were examined. Turkey's determination of its own as well as the carbon potential, these legal and institutional arrangements for examining solutions to do to fulfill the potential use and obligations in international processes have been developed.

The Global Carbon Cycle and Forests: Carbon is one of the most important elements in the world in terms of life. Life influences the regulation of carbon content in the atmosphere dominated by geological forces throughout geological time periods. Earth's heat and carbon content in the atmosphere are linked to geological time scales. Carbon cycle processes take place between hours and millions of years. The global carbon cycle refers to the biochemical cycle of carbon stored in different places on our planet between the pedosphere, hydrosphere, atmosphere, biosphere and geosphere (Lorenz and Lal, 2010). As carbon moves between these reservoirs, the length of stay in each also varies significantly (Mackey et al., 2008).

One of the carbon stocks, the atmosphere contains 839 gigatons of carbon ( $\mathrm{Gt} \mathrm{C}$ ) predominantly in the form of carbon dioxide. The world's largest carbon stock; It is located in the continental crust and upper mantle of the earth $(122.576 .000 \mathrm{Gt} \mathrm{C})$, most of which are formed by sedimentary rocks formed over millions of years. The next largest stock is ocean carbon $(37,100 \mathrm{Gt} C)$. More than $95 \%$ of the carbon found in the ocean is mainly in the form of inorganic dissolved carbon. Only $900 \mathrm{Gt} \mathrm{C}$ is available for exchange on the ocean surface. The oceans release 78.4 Gt $\mathrm{C}$ a year and hold $80 \mathrm{Gt} \mathrm{C}$. Terrestrial systems, on the other hand, emit 119 Gt C per year and keep it at 123 Gt C. Generally, both oceans and terrestrial systems store more carbon than they emit in a year, with $2.3 \mathrm{Gt} \mathrm{C}$ (ocean) per year and 2.6 Gt C (land) per year net intake. Greenhouse gas emissions caused by human activities resulting from fossil fuel consumption and land use change are $9 \mathrm{GtC}$ per year (Janowiak et al., 2017).

In the terrestrial biosphere, carbon is stored in living biomass (450 - $650 \mathrm{PgC}$ ) and in dead organic matter (1500 - $2400 \mathrm{PgC})$ in debris and soils. Wetland soils (300 - $700 \mathrm{PgC}$ ) and frozen soils (1700 PgC) also contain carbon. Carbon dioxide in the atmosphere is transported from the atmosphere through plant photosynthesis and stored within the plant (Gross Primary Production (GPP),

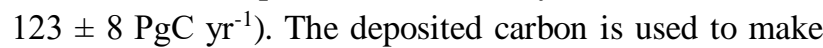
plant tissues. Leaves and branches shed by the plant 
decompose in the soil and stored in the soil as carbon. Plant tissues, debris and carbon in the soil are released back to the atmosphere by plant respiration (autotrophic respiration), microbial soil respiration and animal respiration (heterotrophic respiration) and natural disasters (fire, insect, etc.) A large amount of terrestrial carbon is

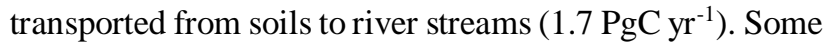
of this carbon is released into the atmosphere as $\mathrm{CO}_{2}$ by rivers and lakes. Some of it is stored in freshwater organic

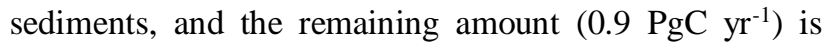
delivered to the coastal ocean as dissolved inorganic carbon, dissolved organic carbon and particulate organic carbon by rivers. Atmospheric $\mathrm{CO}_{2}$ is transported by diffusion between the ocean surface and the atmosphere. In the ocean, carbon is mostly found in the form of Dissolved Inorganic Carbon (DIC, 38,000 $\mathrm{PgC}$ ), which is carbonic acid ( $\mathrm{CO}_{2}$ dissolved in water), bicarbonate and carbon ions, but also as dissolved organic carbon (DOC, $700 \mathrm{PgC}$ ). Marine biota, composed predominantly of phytoplankton and other microorganisms, represents a small pool of organic carbon $(3 \mathrm{PgC})$. Only a small fraction $(\sim 0.2 \mathrm{PgC}$ $\mathrm{yr}^{-1}$ ) of carbon reaches the ocean floor and is stored in sediments (IPCC, 2013b).

According to global calculations made in the last decade between 2007 and 2016, the difference between human-induced emissions released into the atmosphere by sources and removed by sinks was determined as $0.6 \mathrm{GtC} /$ $\mathrm{yr}^{-1}$. This difference in the global carbon cycle is called stock imbalance. The emissions released into the atmosphere are caused by fossil fuel consumption of $9.4 \pm$ $0.5 \mathrm{GtC} / \mathrm{yr}^{-1}$ and industrial facilities. Emissions emitted by land use change were determined as $1.3 \pm 0.7 \mathrm{GtC} / \mathrm{yr}^{-1}$. When we look at the emissions removed by sinks, it is calculated that $4.7 \pm 0.5 \mathrm{GtC} / \mathrm{yr}^{-1}$ is stored by the

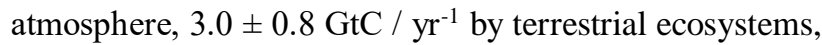
and $2.4 \pm 0.5 \mathrm{GtC} / \mathrm{yr}^{-1}$ by the oceans (Le Quere et al., 2018).

In this period, $88 \%$ of the emissions were caused by fossil fuel consumption and industrial facilities, and $12 \%$ from land use change. While $44 \%$ of the total emissions were shared between the atmosphere, $28 \%$ between the terrestrial ecosystem and $22 \%$ between the ocean, the remaining 5\% was the stock imbalance (Le Quere et al., 2018). The reasons for this stock imbalance are; re-growth of forests can be explained as various processes in plant growth, including carbon dioxide fertilization, nitrogen storage and their interactions (Schimel, 2006).

The world's forest area is approximately 4 billion hectares, and this amount corresponds to $31 \%$ of the total terrestrial area (FRA, 2010). Forests, which contain three quarters of the terrestrial biological diversity, constitute about half of the terrestrial carbon pools. Therefore, forests come to the fore in regulating the world climate (FAO, 2008).

According to the Forest Resources Assessment Report (FRA) (2010), forests at a global scale store $289 \mathrm{Gt}$ of carbon only in their biomass. Globally, forests store 650 billion tons of carbon, $44 \%$ of which is biomass, $11 \%$ of dead wood and debris, and $45 \%$ in soil. Sustainable management, planting and rehabilitation of forests increase forest carbon stocks, while deforestation, forest degradation and poor management of forests reduce this stock. Globally, carbon stocks in forest biomass have been estimated to decline by $0.5 \mathrm{Gt}$ annually over the period 2005-2010. The main reason for this is the decrease in the global forest area. While 16 million hectares of forest area was destroyed annually in the 1990s, approximately 13 million hectares of forest area have been destroyed due to changes in land use and natural reasons since the 2000s.

Emissions Trading: An Annex-I Party that has a commitment to quantify emission limitation and reduction within the scope of the Emission Trade, which is included in Article 17 of the Kyoto Protocol and is a market-based mechanism, may procure or transfer Kyoto units from another Annex-I Party. It can use these acquired units to meet some of their commitments in Article 3 of the Protocol.

In other words, countries emitting less than the committed emission amount can sell the excess emission units they obtain to the Parties that emit more than the committed emission amount (Dagoumas et al., 2006).

With the emission trade, the parties also include the removal units (RMU) obtained from land use land use change and forestry activities, certified emission reduction units (CERs) obtained from project activities carried out within the scope of the Clean development mechanism and emission reduction units (ERUs) obtained from Joint Execution projects. they can transfer within the scope of the system.

The amount of units transferred by the Party to other countries is limited to the commitment period reserve of the Party. Each Party is obliged to preserve the minimum level of units' reserve in its national register in order to prevent Parties from being unable to meet their emission targets by transferring excess units. Known as the "commitment period reserve", this reserve must equal $90 \%$ of the Party's allocated unit of quantity or $100 \%$ of the Annex-A emissions from the most recently reviewed inventory. This reserve, known as the commitment period reserve, cannot be less than $90 \%$ of the allocated amount of the Party or less than 5 times the Annex-A emissions (8 for $\mathrm{KP} 2$ ) of the last revised inventory. Whichever is the lowest is considered (UNFCCC, 2005).

The transfer and purchase of these units are tracked and recorded through the Kyoto Protocol 
registration system. The international transaction record (ITL) ensures that emission reduction units are securely transferred between countries. Thus, a new commodity subject to trade in the form of emission reduction or removal was created. Since carbon dioxide is the main greenhouse gas, the term carbon trade is used. Carbon is now traced and traded like any other commodity. This is known as the "carbon market".

\section{MATERIALS AND METHOD}

Data Collection: In the study, many studies in the literature on climate change, carbon economy and emission trade and international conventions, protocols, meeting and conference final declarations related to the emergence and functioning of carbon markets were also used as material. Especially in Turkey, carbon markets, legal and institutional report prepared by the relevant ministries for the section dealing with regulations, national action plans and strategy documents were also used.

Methods: Literature review method was used in the study. First of all, detailed information on the subject was obtained and analyzed. The deductive method was used to form the conceptual framework of the study. First of all, the concepts of global warming, carbon cycle, and climate change were introduced and carbon markets formed as a result of international processes were explained. In addition, general information was given on forests and the place of the forestry sector in the carbon cycle. Again, subjects such as forestry projects, certification processes and pricing within the scope of carbon markets have been examined in detail depending on the literature. Also next to the position of Turkey in the carbon market, the situation in the international process, scientific and technical infrastructure and legal and institutional arrangements were discussed.

\section{RESULTS AND DISCUSSION}

Forest Carbon Sequestration Potential of Turkeyy: LULUCF party Annex I countries are obliged to submit their greenhouse gas inventory reports and common reporting format (CRF) tables to the LULUCF Secretariat on April 15, at the latest every year. In this context, NIR (2019), our last national inventory report submitted to the secretariat; The total amount of the attitude of Turkey in the LULUCF sector is calculated as $99.907 \mathrm{kt} \mathrm{CO}_{2} \mathrm{eq}^{-1}$. The areas subject to calculation within the scope of the inventory are: forest land, agricultural land, meadow and pasture areas, wetlands, residential areas, harvested forest products, other lands and others.
Table 1. The total emissions and removals in the LULUCF sector in Turkey.

\begin{tabular}{|c|c|c|c|c|c|c|c|c|}
\hline & 1990 & 1995 & 2000 & 2005 & 2010 & 2015 & 2016 & 2017 \\
\hline $\begin{array}{l}\text { Total (kt } \\
\mathrm{CO}_{2} \text { eq.) }\end{array}$ & -55.765 & 57.400 & 61.556 & 74.693 & 73.492 & 97.206 & 95.930 & 99.907 \\
\hline $\begin{array}{c}\text { 4.A } \\
\text { Forest }\end{array}$ & -52.830 & $\overline{54.963}$ & $\begin{array}{c}- \\
57.890\end{array}$ & 69.356 & $\begin{array}{c}- \\
67.614\end{array}$ & $\begin{array}{c}- \\
87.669\end{array}$ & 85.233 & 90.195 \\
\hline $\begin{array}{l}\text { Area } \\
\text { 4.B }\end{array}$ & & & & & & & & \\
\hline $\begin{array}{c}\text { Farming } \\
\text { Area }\end{array}$ & 0.69 & 153 & 38 & 207 & 453 & 457 & 344 & 368 \\
\hline $\begin{array}{c}\text { 4.C } \\
\text { Pasture } \\
\text { Area }\end{array}$ & 0.03 & 262 & 81 & 211 & 551 & 929 & 592 & 640 \\
\hline $\begin{array}{c}\text { 4.D } \\
\text { Wetland }\end{array}$ & 12 & 169 & 188 & 40 & 426 & 93 & 344 & 328 \\
\hline $\begin{array}{c}\text { 4.E Work } \\
\text { Area }\end{array}$ & NO,IE & 132 & 145 & 273 & 426 & 419 & 406 & 413 \\
\hline $\begin{array}{c}\text { 4.F Other } \\
\text { Area } \\
\text { 4.G }\end{array}$ & NO & 181 & 187 & 310 & 601 & 764 & 617 & 653 \\
\hline $\begin{array}{c}\text { Harvested } \\
\text { Wood } \\
\text { Product }\end{array}$ & -2.948 & -3.333 & -4.305 & -6.379 & -8.334 & $\begin{array}{c}- \\
12.200\end{array}$ & $\begin{array}{c}- \\
13.000\end{array}$ & 12.115 \\
\hline
\end{tabular}

Turkey's LULUCF sector, providing a net removal. Forests have a large share in the removal of this sector. Within the LULUCF sector, the emission attitude amount of forest areas has been determined as $90.195 \mathrm{kt}$ $\mathrm{CO}_{2} \mathrm{eq}^{-1}$. The attitude amount provided by the harvested wood products (HWP) sector is $12.115 \mathrm{kt} \mathrm{CO}_{2} \mathrm{eq}^{-1}$. Other land uses generated net emissions. LULUCF sector has increased by $79.2 \%$ compared to 1990 . In 2017, total $\mathrm{CO}_{2}$ emissions and removals in the LULUCF sector increased by $4.1 \%$ compared to 2016 .

Significant improvements have been made in the LULUCF reporting system. With the new system, transparency increased, integrity, accuracy and consistency were improved. Land use definitions have been updated with the new land monitoring system. The forest definition used in NIR 2018 is a national legal definition with a threshold value of 3 hectares, while in the new definition, the forest area is divided into 2 sub-categories as fertile forest and other forest area. The fertile forest has been defined as the trees and shrubs larger than 1 hectare, which grow naturally and with human influence, with more than $10 \%$ coverage. The other forest area is defined as trees and shrubs larger than 1 hectare, which grow naturally and with human impact, with less than $10 \%$ coverage. Inconsistency between forestry and other land use activity data has been corrected. Providing area, increment and other data on forests, ENVANIS was based on the national legal definition as a forest area. This definition did not allow the creation of land use matrices consistent with CORINE used as a land cover map. The new Satellite-based land cover monitoring system provided the opportunity to monitor every 1 hectare of land unit. In this way, since 1990 , matrixes regarding land transformations and land uses have been developed and no duplicate calculations or skips have been made. Ecological zones have been associated with established climate types. 
Turkey's Position in the International Process: Turkey, the United Nations Climate Change in the Framework Convention adopted in 1992, the Economic Cooperation and Development Organization's Convention on account of being a member of both Annex I and Annex II list, has been involved with the developed countries. Turkey since 1992, supporting the purpose and the general principles of contract together not a party to the contract due to the unfair position in the contract and gave a long struggle to change that position. Made on the Moroccan city of Marrakech in 2001 7th Conference of Parties (COP.7), "Turkey's name to be deleted from Annex II and the special circumstances recognized and other Annex I will include in Annex I in a different location in the country Became a party to the contract on 24 May 2004 following the decision.

The Draft Law on the appropriate location of our participation in Kyoto Protocol "05 February 2009, the Grand National Assembly of Turkey was adopted by the General Assembly and as of 26 August 2009 Turkey was formally ratified the Kyoto Protocol. Turkey's first Kyoto Protocol (2008-2012) and Second (2013-2020) Liability Period There is no greenhouse gas emission reduction commitments. It became a party to the Paris Agreement on 22 April 2016 and submitted the National Contribution Declaration on 30/09/2015.

Situation in Turkey's Emissions Trading System: The World Bank has implemented a technical assistance program called the "Partnership for Carbon Market Readiness (PMR)" to provide developing countries and emerging economies with the development of the necessary capacity to actively benefit from market mechanisms.

Multi Donor Fund for the Grant Agreement Carbon Market Readiness Partnership (PMR) Partnership support program was implemented by the World Bank and the Undersecretariat of Treasury, numbered TF010793, made by the World Bank and the Undersecretariat of Treasury. Fund Grant numbered TF015591 for the Partnership for Preparation for the Carbon Market was published in the Official Gazette numbered 28910 on 11 February 2014. With contracts, 3,350,000 dollars were allocated to the Ministry of Environment and Urbanization. The Ministry of Environment and Urbanization has been designated as the Implementing Agency for the above mentioned Grant Agreement.

A pilot study in coordination with all relevant stakeholders for the implementation of the Regulation on Monitoring of Greenhouse Gases (MRV) in voluntary sectors, analytical studies, capacity building, awareness raising and training studies to support decision-making processes for the use of carbon market mechanisms will be carried out within the scope of the project.
In April 2012, Turkey has adopted a new regulatory framework for a comprehensive and compulsory MRV system. Monitoring and reporting in 2015 (2015 emissions) started in 2016.

Turkey, since 2013, energy, cement and refinery sectors through pilot studies in order to improve the regulation MRV is working with PMR. A series of workshops and analytical studies have been conducted to explore the options for using emission trading and other market-based tools in MRV sectors.

A synthesis report in November 2018 Climate Change and Air Management stating that carbon markets of policy options were presented to the Coordination Committee for Turkey.

Turkey is a candidate at the same time EU membership and thus aims to fulfill its environmental obligations of EU membership (including the EU ETS Directive) MRV Turkey MRV legislation has established a system at the installation level for $\mathrm{CO}_{2}$ emissions for about 900 businesses. The scope of the sector includes the energy sector (combustion fuels $>20 \mathrm{MW}$ ) and industrial sectors (coke production, metals, cement, glass, ceramic products, insulation materials, paper and pulp, chemicals according to specified threshold sizes / production levels) ( ICAP, 2019).

Status of Forest Carbon Credits in Voluntary and Mandatory Markets: Compared to the mandatory markets, the forestry sector took a higher place in voluntary markets as a transaction volume. While the value of voluntary forest carbon offset transactions in 2016 was 74.2 million dollars, it was 551.4 million dollars when 41.9 million dollars excluding the Australian ERF in mandatory markets were included. $2 / 3$ of the voluntary markets in total transaction value were obtained from forestry carbon offsets. The transaction volume decreased by $21 \%$ in 2016 compared to 2015 .

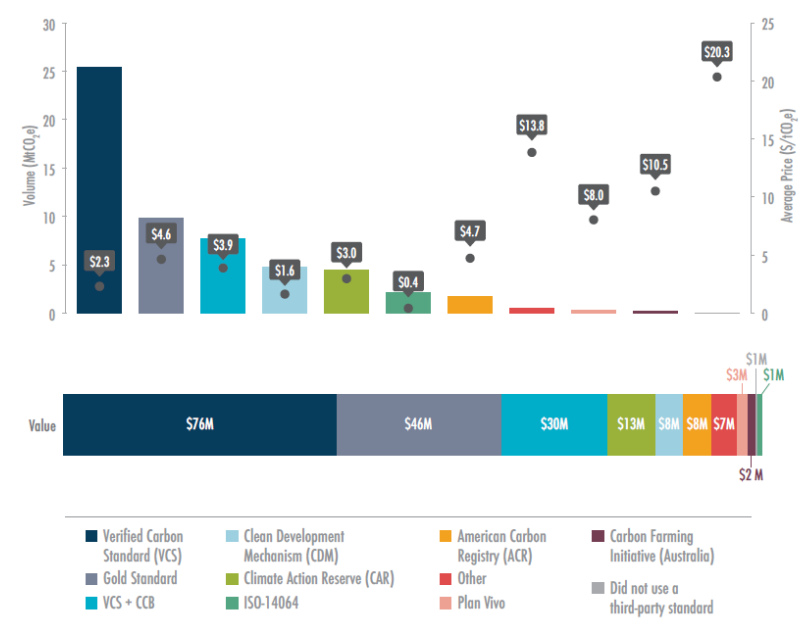

Figure 1. Transaction volume and values of forestry-based emission reductions in voluntary and compulsory markets (Hamrick and Gallant, 2017). 
The activities used to create forest carbon credits under CDM in mandatory markets are afforestation and reforestation. According to the latest data, only 66 of 7804 registered CDM projects are forestry projects and the share of A / R loans in CDM loans is only $0.8 \%$. The important reason for this is the difficulties it faces in terms of proving the additional contribution and effectiveness. Within the scope of the Paris Agreement, negotiations on CDM are continuing.

Forestry and land use projects in the voluntary carbon market are certificated and traded within the framework of certain standards. These standards; Verified Carbon Standard (VCS), American Carbon Registration Standards (ACR), Plan Vivo Standard, Gold Standard, Climate Action Reserve (Reserve) CAR and Climate, Community and Biodiversity Standards (CCB Standards).

$82 \%$ of forestry and land use projects in the voluntary market have the Verified Carbon Standard. Different project types such as tree-planting, agroforestry and advanced forest management are certified within the scope of VCS. But the most common is REDD +. $73 \%$ of VCS certified offsets also carry Climate Community and Biodiversity (CCB) Standards. The CCB standard is a noncarbon common benefit standard and is added to VCS forest carbon projects. Historically, VCS and CCB certified offsets have been sold at higher prices than those approved by VCS alone, but this did not apply in 2016 . VCS certified offsets average $\$ 4.6 / \mathrm{tCO}_{2}$ equivalent, VCS $+\mathrm{CCB}$ offsets $4.1 / \mathrm{tCO}_{2}$ equivalent sold. This is probably due to the locations of these projects; VCS + CCB Offset prices tend to be produced in low-income countries, with offset prices generally lower. ACR certified offsets made up the second largest share of the market in terms of value and volume in 2016. Most of the offsets published by the processed ACR came from either improved forest management or tree planting. ACR offsets are $8.9 \$ / \mathrm{tCO}_{2}$ equivalent above average prices. This is partly because ACR certified projects are mostly found in the United States. The Gold Standard and Plan Vivo both place great emphasis on shared benefits and although they have no geographic constraints, both standards approve forestry and land use projects in small, rural communities in lowor middle-income countries. Gold Standard accounts for about $4 \%$ of the market volume, with these offsets traded at an average price of $\$ 5.7 / \mathrm{tCO}_{2}$ equivalent. Tree planting constituted the main project type. Plan Vivo accounted for $2 \%$ of the market volume and these offsets were traded at an average price of $\$ 8 / \mathrm{tCO}_{2}$. Plan Vivo is forest project types-tree planting, agro-forestry, mangrove restoration, REDD + and advanced land and forest management. In 2016, project transactions that did not use a third-party verification standard accounted for only $0.3 \%$ of the market volume and were sold at the highest price $(20.1$ \$ /
$\mathrm{tCO}_{2}$ equivalent). Offsets in the 'other' category also accounted for the second highest price $\left(11.5 \$ / \mathrm{tCO}_{2}\right.$ equivalent), but they accounted for less than $1 \%$ of total forest and land use offsets, all of which are in North America, where prices are higher. are available. Similarly, the Australian Carbon Agriculture Initiative offsets have high prices (average $8.9 \$ / \mathrm{tCO}_{2}$ equivalent), making up a very small portion of the market $(2 \%)$ and were used only in Australia. 99\% of all forest carbon projects include at least one co-benefit type (Hamrick and Gallant, 2017).

Voluntary carbon markets In 2016, more than US \$ 66 million forest carbon offset projects were processed. These offset projects have $99 \%$ VCS standards.

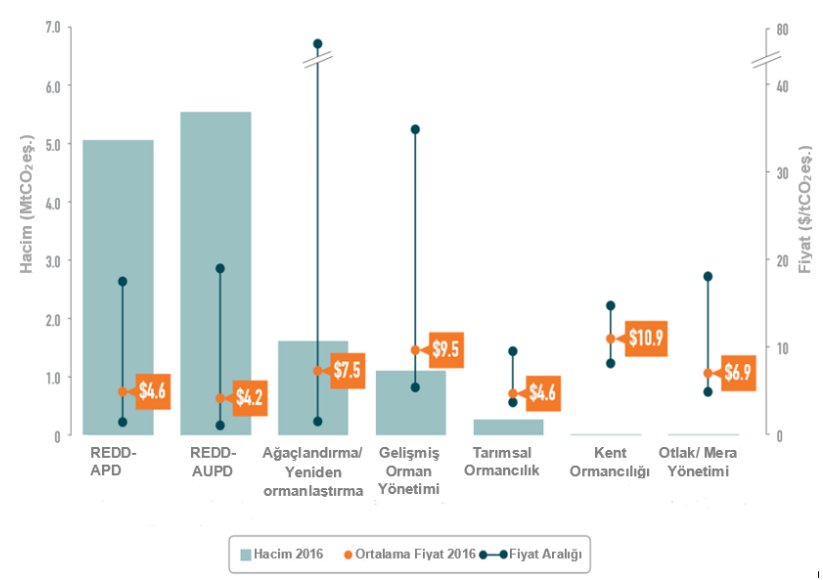

Figure 2. Distribution of forestry carbon projects by project type.

When Figure 2 is examined, $26.8 \%$ of the traded volume constitutes the forestry and land use category. $46.5 \%$ of the total value of voluntary carbon markets comes from forestry and land use offsets. Renewable offsets sold at an average of $\$ 1.4$, while forestry and land use offsets were sold at \$ 5.1 (Hamrick and Gallant, 2017).

In 2016, the most traded project categories in the voluntary carbon markets were renewable energy resources with a transaction volume of $18.3 \mathrm{MtCO}_{2}$ equivalent, and forestry and land use with a transaction volume of $13.1 \mathrm{MtCO}_{2}$.

According to the project types the transaction volume of the forestry and land use category in the voluntary carbon markets in 2016 was $13.1 \mathrm{MtCO}_{2}$ equivalent. The volume of forestry project types in this category was $12.1 \mathrm{MtCO}_{2}$ equivalent. REDD + project type 9.7 $\mathrm{MtCO}_{2}$ equivalent, Afforestation and Reforestation (A / R) $1.3 \quad \mathrm{MtCO}_{2}$ equivalent and Advanced Forest Management (IFM) with $1.1 \mathrm{MtCO}_{2}$ equivalent volume have taken place in this market. In 2016, the most purchased and sold project type in terms of volume was 9.7 $\mathrm{MtCO}_{2}$ equivalent and wind energy followed REDD + with 8.2 $\mathrm{MtCO}_{2}$ equivalent. The average price of offsets from the REDD + project type was $\$ 4.2$, Afforestation and Reforestation (A / R) offsets averaged \$ 8.1, Advanced 
Forest Management (IFM) offsets were traded at $\$ 9.5$ (Hamrick and Gallant, 2017).

Approximately one-third of carbon credits in voluntary markets are from forest carbon credits. The majority of forest carbon credits are generated in developing countries. Recently, the supply in the market is high and the price of loans remains low. In forest carbon projects, the $\mathrm{CO}_{2}$ price per tonne varies between 3 and 10 US dollars.

Carbon Market in Turkey: Turkey, although the Kyoto Protocol does not benefit from the flexibility mechanisms which are subject to emissions trading in functioning independently of these mechanisms, established within the framework of environmental and social responsibility principles Volunteer projects for the Carbon Market has long been developed and implemented (NC, 2016). Voluntary Carbon Market, if we represent a very small percentage in the World Carbon Market, effective way to benefit from this market in Turkey offers an important opportunity for future participation in the carbon market. Currently, there are 348 projects that improve the carbon presence in the Voluntary Carbon Market. These projects are expected to achieve 26 million $\mathrm{CO}_{2}$ equivalent greenhouse gas emissions annually ( $\mathrm{NC}$, 2017). $72 \%$ of voluntary carbon projects project is located in the top five countries hosting: India (442), China (426), United States (351), Turkey (124) and Brazil (97) (Hamrick and Gallant, 2017).

Table 2. Industry distribution of the carbon project in Turkey (NC, 2017).

\begin{tabular}{lcc}
\hline Project Type & Number of Project & $\begin{array}{c}\text { Annual Potential of GHG } \\
\text { Emission Reduction (tCO2-eq) }\end{array}$ \\
\hline Hydroelectric & 146 & 8.543 .540 \\
Wind Power & 145 & 11.223 .783 \\
Biogas/ Waste Energy System & 34 & 4.104 .066 \\
Geothermal & 11 & 1.868 .256 \\
Energy Efficiency & 12 & 268.557 \\
TOTAL & 348 & 26.008 .202 \\
\hline
\end{tabular}

Turkey plays a significant role in the global voluntary carbon market and is the largest seller of voluntary carbon credits in Europe. 2007-2015 period, Turkey has made 35 million tonnes of $\mathrm{CO}_{2}$ equivalent transactions with a value of over $\$ 200$ million. This transaction volume represents around 70 percent of the total market volume in Europe so far. Turkey in 2015, 3.1 million tons, which is about half of all primary operations in Europe are responsible for the $\mathrm{CO}_{2}$ equivalent. This is Turkey equally with other major players, including the United States and Kenya after Brazil, India and Indonesia has the world's fourth largest provider of voluntary carbon exchange. However, despite the high transaction volume, the total value of these transactions fell from USD 18.6 million in 2013 to USD 4.3 million in 2015. Most of
Turkey's voluntary carbon transactions, wind, were obtained from the sale of VERs generated by hydro and landfill methane projects.

Turkey average price of $\$ 1.1$ with traded volume of $1.9 \mathrm{MtCO}_{2}$ equivalent in 2016 from is stated that the total value of $\$ 2 \mathrm{M}$.

Carbon projects in Turkey is primarily developed in one of the two standards. These; It is Gold Standard and Verified Carbon Standard. As of April 2016 Turkey, has completed 235 projects registered with the Gold Standard which 125 of them, 110 of them are Verified Carbon Standard. Both standards stand out as an internationally respected framework for the development and implementation of emission reduction projects and are traded worldwide.

The basis of the United Nations Framework Convention on Combating Climate Change and its accompanying Kyoto Protocol is based on the "polluter pays" philosophy. Parties have made emission reduction commitments in line with this philosophy. However, for both economic and political reasons, developed countries with historical responsibility have taken less emission reduction commitments than they could. While Kyoto Protocol's first term emission reduction target was 5\%, this target was realized as $22.6 \%$ at the end of the period. This situation reveals that especially developed countries make less effort in combating climate change than they can.

Since the developed countries that are party to the contracts have completed their industrialization, current emission trends are lower than those in developing countries that cannot complete their industrialization. However, developed countries, which have been in a polluting position in the historical process, do not make enough effort and continue to contribute to their economies by transferring technology to developing countries through mechanisms. For example, while the Green Climate Fund, whose establishment purpose is to provide funds to developing countries from developed countries in adaptation to climate change, 100 billion dollars should be transferred until 2020, it was announced at the Lima Conference that the amount provided for this fund was only 10 billion dollars.

Although the issue of climate change is an environmental reality today, the economic and political attitudes of the party countries have a negative effect on the solution of this problem. Some of the developed countries (Japan, Australia, Canada, Russia) that have emission reduction and limitation targets in the first period of the Kyoto Protocol are not included in the second period of the Kyoto Protocol with the Doha Regulation. One of the main factors for countries to make this decision is the avoidance of emission reduction commitments by major economies such as the USA, India and China. Again, since the second 
period emission reduction target of the Kyoto Protocol is $18 \%$, these countries did not take part in the second period of the Kyoto Protocol in order to avoid the negative effects to be experienced on their industries and thus on their economies.

A study examining the share of sectors in KP1 emission reductions revealed that the energy sector contributed to the highest greenhouse gas emission reductions, with most countries achieving a limited amount of greenhouse gas reductions from their chosen LULUCF activities. It has been determined that LULUCF's contribution to greenhouse gas emission reduction has a significant but small share. This suggests that unless there are significant changes in accounting rules, future emission reductions will mainly result from actions to reduce fossil fuel consumption, and the agriculture and LULUCF sectors will continue to play a supporting role (Liua et al., 2016).

According to 2016 data, the total volume of the global carbon market is $6.03 \mathrm{GtCO}_{2}$ and its monetary value is 30.2 billion dollars. Almost all (99\%) of the trading volume of the carbon market consists of mandatory markets. Mandatory markets have a trading volume of 5.96 $\mathrm{GtCO}_{2}$ and a monetary value of approximately \$ 30 billion. When the carbon credits obtained from forestry projects traded in compulsory and voluntary markets are analyzed; While the total amount of forest loans traded in the mandatory market is 41.9 million dollars, this value is 74.2 million dollars in voluntary markets. While carbon credits obtained from forestry projects constitute $37.1 \%$ of the total value of voluntary markets, these credits constitute $0.14 \%$ of the compulsory market. Forests are of great importance in efforts to combat global climate change. For this reason, this situation has been emphasized and continues to be done in all international processes, especially the Kyoto Protocol. However, forestry carbon credits cannot be traded in most of the existing mandatory markets (limited trade in New Zealand and Canada), especially in the European Union Emission Trading System. The reason for this situation; countries evaluate their forestry projects within the scope of risky investment.

Parties taken so far regarding Turkey Conference decisions 26 / CP.7, 1 / CP.16, 2 / CP.17 1 / CP.18 and 21 / CP.20 'dir. There has been no change in the state of Turkey. Turkey, in a different location from the UNFCCC's other Annex I Parties, the particular circumstances of the well-known, not included in the agreement's Annex II list, as defined in KP's Annex-B binding greenhouse gas does not have any commitment to reduce emissions. Turkey constitute the basic principles of historical responsibility for the contract, the principle of common but differentiated responsibilities, equity and revise again the differences in the classification of countries is important Annex.

Turkey has not yet ratified despite the signing of the Paris Agreement. Turkey, the necessary arrangements in the energy sector in reducing the use of fossil fuels $2 \mathrm{C}$ temperature increase within the confines of this agreement is one of the declared objectives would do. However, CAT (2019), of which Turkey is a country located in (the US, Russia, like Saudi Arabia) at the National Contribution Statement was found critically inadequate. Turkey's growing energy demand planning to meet the new coal power plants sourced from literally create a contrast with the National Contribution Agreement under the Paris Declaration. Turkey, 88'n\% of its energy needs, according to data of 2017 , or $33 \%$ of the fossil fuel and electricity supply (16\% increase compared to 2016) have met from the coal. In this case, the CAT (2019) to verify the report with the revision of policy towards Turkey, especially renewable energy sources reveals the necessity. Also, in case the point of meeting the targets set by Treaty of Paris that Turkey is not sufficient in forestry legislation and in particular to continue to be considered as developed countries needed extensive editing is in Turkey's forestry legislation (Gencay et al., 2019).

Bouyer and Serengil (2017) in Turkey between the years 2013- 2020 forest carbon credits that can be obtained from 179.1 $\mathrm{MtCO}_{2}$ (nearly $22.4 \mathrm{MtCO}_{2}$ ) found equivalent. In this study, the cost per ton was found as 66.7 dollars for forest management and 86.4 dollars for afforestation. These values indicate that only very costly for the operation of Turkey's forests and carbon sequestration is quite high in terms of producing only carbon projects in terms of retention, although low compared to other sectors.

Kuş et al. (2017) entitled, obtain carbon credits from afforestation and reforestation projects in the voluntary carbon market in Turkey The legal and technical conditions have been examined. Working with Turkey hectare basis with a small amount to be obtained $\mathrm{A} / \mathrm{R}$ carbon credits were increased disproportionately the certification costs and a 30-year A/R project of the cycle carbon certification cost was estimated that approximately \$ 110,000. Project design development, registration, approval and verification processes are included in this cost calculation and excluding afforestation cost and net present value. In order to earn income from carbon credit sales, it was estimated that an area of 187 hectares should be subject to afforestation. providing reforestation carbon certification in the private sector in the implementation of the socio-economic responsibility program in Turkey has observed that the economically and technically.

Turkey, the world takes its place among the few countries that increase the presence of the forest. In 
combating climate change, the forestry sector is important in terms of mitigation and adaptation policies. One of the ecosystem services provided by forests is that it acts as a sink in terms of greenhouse gas emissions. Therefore, the effect of correct and sustainable management of forests on carbon stocks is indisputable. Turkey, however, inadequate to the legal framework on this issue (Coskun and Gencay, 2011), the institutional embodiment there are shortcomings. Yet rural development with forestry activities in Turkey in the fight against climate change and the use of tools such as agroforestry is important (Toksoy and Bayramoglu, 2017). Positive effects can be made on issues such as reduction of greenhouse gas emissions and biodiversity as well as increasing the welfare levels of regional development and rural societies through both rural development and agricultural forestry studies (Toksoy and Bayramoğlu, 2020).

\section{CONCLUSION}

The following recommendations are developed alongside of climate change more effectively use the carbon markets and forestry projects located in the struggle with Turkey's on what to do about it.

- For the continuity of the mechanisms established by the Kyoto Protocol, first of all, developing countries should fulfill their economic obligations.

- Countries with similar economic indicators should be re-evaluated and the classification should be revised in order to correct the problems in the country classification made as a result of international processes.

- In order to make carbon markets more effective and efficient, besides taking into account the special circumstances of the countries in the creation of new market rules, practices that encourage the market should be encouraged.

- As a carbon pricing mechanism in the fight against climate change, regulations are made to encourage Carbon Markets private sector solutions. Particularly with regard to the issue of forestry forest ownership in Turkey does not permit the private sector to take part in this market. Must make the necessary arrangements in this regard the relevant public institutions and organizations in Turkey.

-Turkey's strong international position with the change, measurable - verifiable - reportable (MRV) are required to establish the system. For this, institutional capacity should be developed first.

- In Turkey, the only competent authority responsible for the management of the forests within the General Directorate of Forestry will conduct studies on the fight against climate change at a level sufficient (nowadays are active in the working group level) does not have a unit.
The General Directorate of Forestry should establish a unit at the level of departments on climate change in its current structure, and give importance to developing its institutional capacity and training expert teams.

\section{ACKNOWLEDGMENTS}

The authors declare that there are no conflicts of interest. This study is derived from the master thesis "Stiuation of Forest Carbon Projects in Carbon Markets" conducted in the Karadeniz Technical University, Institute of Science, Forest Engineering Department. This study was presented in ORENKO 2020 held by Karadeniz Technical University, Trabzon.

\section{REFERENCES}

Bouyer, O. \& Serengil, Y. (2017). Cost-Benefit Assessment of Implementing LULUCF Accounting Rules in Turkey. In: Carbon Management, Technologies, and Trends in Mediterranean Ecosystems. Springer, Dordrecht, 89-129p.

CAT. (2019). Warming Projections Global Update, London, UK, 33p.

Coşkun, A.A. \& Gençay, G. (2011). Kyoto Protocol and "Deforestation" A Legal Analysis On Turkish Environment And Forest Legislation. Forest Policy and Economics, 13(5), 366-377.

Dagoumas, A.S., Papagiannis, G.K. \& Dokopoulos, P.S. (2006). An economic assessment of the Kyoto Protocol Application. Energy Policy, 34(1), 2639.

FAO. (2008). Strategic Framework for Forests and Climate Change, Forest Day, Poznan, 57p.

FRA. (2010). Global Forest Resources Assessment 2010 Main Report, FAO Forestry Paper 163, Rome, $378 \mathrm{p}$.

Gençay, G., Birben, Ü. \& Aydın, A. (2019). To Be “A Developed Country" Or Not To Be? The Effect Of The Paris Agreement On Turkish Forest Law. Environ Monit. Assess., 191(2109), 1-14.

Hamrick, K. \& Gallant, M. (2017). Fertile Ground State of Forest Carbon Finance 2017. Wahington, USA, $88 \mathrm{p}$.

ICAP. (2019). Emissions Trading Worldwide: Status Report 2019. Berlin, Germany, 12p.

IPCC. (2013a). Summary for Policymakers. In: Climate Change 2013: The Physical Science Basis. Contribution of Working Group I to the Fifth Assessment Report of the Intergovernmental Panel on Climate Change, Cambridge University 
Press, Cambridge, United Kingdom and New York, NY, USA.

IPCC. (2013b). Carbon and Other Biogeochemical Cycles. In: Climate Change 2013: The Physical Science Basis. Contribution of Working Group I to the Fifth Assessment Report of the Intergovernmental Panel on Climate Change. Cambridge University Press, Cambridge, United Kingdom and New York, NY, USA.

IPCC. (2014). Climate Change 2014: Synthesis Report. Contribution of Working Groups I, II and III to the Fifth Assessment Report of the Intergovernmental Panel on Climate Change. IPCC, Geneva, Switzerland, 151p.

Janowiak, M., Connelly, W.J., Dante-Wood, K., Domke, G.M., Giardina, C. et al., (2017). Considering forest and grassland carbon in land management General Technical Report (GTR),WO-95, USDA Forest Service, Washington, 76p.

Kuş, M., Ülgen, H., Güneş, Y., Kırış, R., Özel, A. \& Zeydanl, U. (2017). Carbon Certification of Afforestation and Reforestation Areas in Turkey. In: Erşahin, S., Kapur, S., Akça, E., Namlı, A. \& Erdoğan H.(Eds), Carbon Management, Technologies, and Trends in Mediterranean Ecosystems. The Anthropocene: PolitikEconomics-Society-Science 15, Springer, 159p.

Le Quéré, C., Andrew, R.M., Friedlingstein, P., Sitch, S., Hauck, J. et al. (2018). Global Carbon Budget 2018. Earth Syst. Sci. Data, 10, 2141-2194.

Liua, S., Wilkes, A., Lia, Y., Gaoa, Q., Wana, Y., Maa, X. \& Qin, X. (2016). Contribution of different sectors to developed countries' fulfillment of GHG emission reduction targets under the first commitment period of the Kyoto Protocol. Environmental Science \& Policy, 61, 143-153.

Lorenz, K. \& Lal, R. (2010). Carbon Sequestration in Forest Ecosystems. Springer, Dordrecht, 239p.

Mackey, B.G., Keith, H. Berry, S.L. \& Lindenmayer, D.B., (2008). Green Carbon: The Role Of Natural
Forests in carbon storage. Part1. A Green Carbon Account Of Australia's South-Eastern Eucalypt Forests And Policy Implications. ANU Press, Canberra, 47p.

NC. (2016). Sixth National Communication Of Turkey. Republic of Turkey Ministry of Environment and Urbanization, Ankara, 155p.

NC. (2017). Seventh National Communication Of Turkey. Republic of Turkey Ministry of Environment and Urbanization. Ankara, 195p.

NIR. (2019). National Inventory Report. Turkish Statistical Institute, Ankara, 567p.

Öztekin, Ç. (2019). Stiuation of forest carbon projects in carbon markets and assessment of turkey. Master Thesis, Natural Sciences, Karadeniz Technical University, Trabzon, Türkiye, 128p.

Serengil, Y. (1995). Küresel Isınma ve Olası Ekolojik Sonuçları. Journal of the Faculty of Forestry, 45(1-2), 135-152.

Schimel, D. (2006). Terrestrial Ecosystem and Carbon Cycle. Global Change Biology, 1(1), 77-91.

Toksoy, D. \& Bayramoğlu, M.M. (2017). Rural Development and Forest Villages. KTU Publications No:244, Trabzon, Turkey, 232p.

Toksoy, D. \& Bayramoğlu, M.M. (2020). Agricultural Forestry. Serander, Trabzon, Turkey, 200p.

UNFCCC. (1992). United Nations Framework Convention On Climate Change. FCCC/INFORMAL/84, GE.05-62220,(E) 200705, Rio, Brazil, 25p.

UNFCCC. (2005). Report of the Conference of the Parties serving as the meeting of the Parties to the Kyoto Protocol on its first session, held at Montreal from 28 November to 10 December 2005, Addendum, Part Two: Action taken by the Conference of the Parties serving as the meeting of the Parties to the Kyoto Protocol at its first session, 11/CMP.1 Modalities, rules and guidelines for emissions trading under Article 17 of the Kyoto Protocol, FCCC/KP/CMP/2005/8/Add.2. 